\title{
The Effect of Product Quality, Service Quality, Customer Satisfaction on Customer Loyalty
}

Received: November 29, 2021 Accepted: February 16, 2022

*Corresponding author: Nurul Fitrianis Naini, Magister Management, Mercu Buana University, Jakarta, Indonesia*

E-mail:

fitrianisnurul@gmail.com

Additional information is available at the end of the article

\author{
Nurul Fitrianis Naini ${ }^{{ }^{*}}$, Sugeng Santoso ${ }^{2}$, Tanti Stevany Andriani ${ }^{3}$, Unique Claudia ${ }^{4}$, \\ Nurfadillah ${ }^{5}$
}

\begin{abstract}
Pujasera Melawai is one area in implementing the DKI Jakarta tourism office program. There are many traditional cuisine menus to choose from, one of which is Restaurant $X Y Z$. This study determines the effect of the product, service quality, \& customer satisfaction on customer loyalty in Restaurant XYZ. This study was based on quantitative methods with data collection using a questionnaire by accidental sampling and qualitative method by interviewing the owner of Restaurant XYZ. Quantitative data was taken by anyone who met the purchase requirements at least two times at Restaurant XYZ. The sample was 100 respondents that were analyzed by regression logistics. Based on the questionnaire result and interview with customers and key informants, the three indicators of product and service quality most influential to customer satisfaction and loyalty are response accuracy, product uniqueness, and employees' attention that makes customers happy and want to return restaurant. Based on the results, customer loyalty has a probability of 76.8 percent affected which product quality and customer satisfaction, service quality affects customer loyalty in Restaurant XYZ.
\end{abstract}

Keywords: loyalty, product, logistic regression, satisfaction, service

JEL Classification: L10, L11, L6, L66

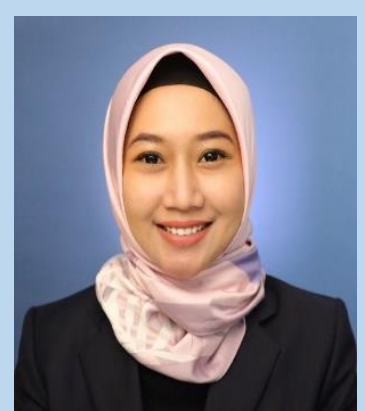

Nurul Fitrianis Naini

\section{ABOUT THE AUTHORS}

Nurul Fitrianis Naini graduated from Bogor Agriculture University (IPB), Indonesia. Her areas of specialization include corporate culture consultant and as part of owner Bebek Misci-chi Surabayan Restaurant, Jakarta, Indonesia. shecould be reached through her email: fitrianisnurul@gmail.com.

Sugeng Santoso is an Associate Professor at the Faculty of Economy and Business, Mercu Buana University, Indonesia. He awarded as The Best Performing Lecturer on Magister Program of Mercu Buana University Academic Year 20192020. His areas specialization includes creative food startup and industrial cluster. He can be reached via sugeng.santoso@mercubuana.ac.id.

Tanti Stevany Andriani graduated from Bina Nusantara University. Her areas of specialization include marketing and entrepreneur in the field of architectural contractor, Jakarta, Indonesia. She could be reached through her email: stevanytanti@gmail.com

Unique Gita Claudia graduated from Syarif Hidayatullah State Islamic University Jakarta, Indonesia. Her area of Specialization is Human Resource and Marketing Support. She could be reached through her email: Uniqqinuclaudia@gmail.com

Nurfadillah graduated from Management, Faculty of Economic and Business, Mercu Buana University, Indonesia. She could be reached through her email: Nurfadilah1097@gmail.com.

\section{PUBLIC INTEREST STATEMENT}

This restaurant sets a relatively cheap price and can be reached by all levels of society and specializes in its special spices in its yellow sauce and chili sauce, thus providing a different taste compared to other restaurants. This makes it a special attraction for the restaurant and can make an excellent strategy in maintaining, developing innovation and marketing promos at this restaurant deliberation the number of similar competitors creates new challenges for companies that are required to be able to maintain and prioritize product quality, so they can satisfy their customers on an ongoing basis. By maintaining good product quality, customers will feel continuous satisfaction so that loyalty is created in their minds.

This study reveals the importance of developing spices that are used for restaurant seasoning and innovation in improving product quality and service quality to customer satisfaction and loyalty at Restaurant $\mathrm{XYZ}$, as well as the hope of stakeholder synergy in the development of the culinary subsector ecosystem. 


\section{Introduction}

The Creative Economy Agency is a non-Ministerial Government Institution that is under and responsible to the president through the minister in charge of government affairs in the tourism sector, with the highest leader called the head who is in charge of assisting the president in formulating, establishing, coordinating, and synchronization of creative economy policies in the field of culinary, one of which is the Creative Economy Agency (BEKRAF, 2019). Culinary is one of the sub-sectors of the creative economy that needs to be developed. The export value of Indonesian processed spices and commodities/fresh spices experienced a positive trend with an average growth of 2.95 percent over the last five years. In 2020, the export value was recorded at 1.02 billion US dollars (KEMENPAREKRAF, 2021).

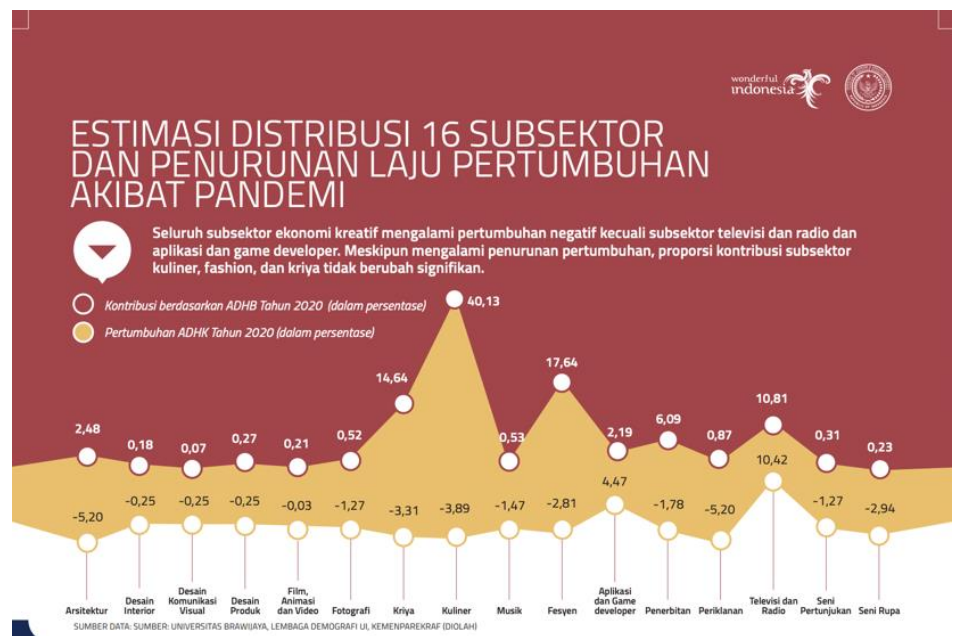

Figure 1. Estimated Distribution of 16 Sub-Sectors and Decreased growth rate due to the pandemic

Based on infographic data from Brawijaya University, UI Demographic Institute, BEKRAF (2019), all creative economic sub-sectors experienced negative growth. However, especially for the culinary subsector, decreased by -389 percent is presented in figure 1.

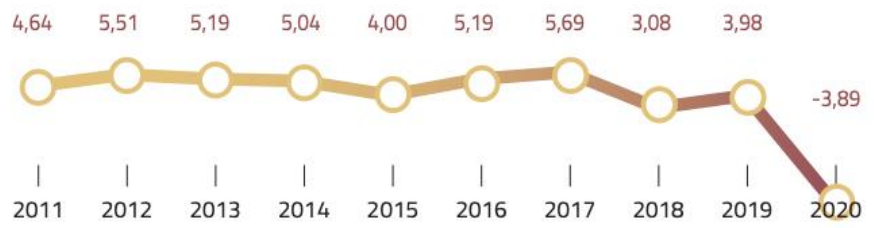

Figure 2. Data on the phenomenon of a decline in economic growth rate according to Culinary Sector to the Infographic of Statistics for Macro Tourism \& Creative Economic Indicators.

Based on BPS, Brawijaya University, UI Demographic Institute, BEKRAF (2019) that architecture and advertising were most affected by the pandemic during 2020, the architecture and advertising sub-sector was the sub-sector that experienced the most drastic decline in growth was, followed by the culinary subsector is presented in Figure 2.

Restaurant XYZ is one of the restaurants located in the Pujasera Melawai area, where the Pujasera Melawai area is one of the programs of the Jakarta Tourism Office. The restaurant was established in 2003 and already has three other branches. Beginning of 2020, the culinary business of Restaurant XYZ began to experience a decline due to the impact of the pandemic. Still, the restaurant carried out several activities in terms of quality, service, and customer satisfaction to support the achievement of 


\section{J O U R N A L O F CONSUMER SCIENCES}

performance income. This restaurant sets a relatively low price and can be reached by all levels of society and specializes in its special spices in its yellow sauce and chili sauce, thus providing a different taste than other restaurants. This makes it a unique attraction for the restaurant and can make an excellent strategy in maintaining, developing innovation and marketing promos at this restaurant, also able to support the program of the minister of tourism and creative economy or head of the tourism and creative economy agency, "Indonesia spice up the world" is expected to increase Indonesia's opportunities in the culinary industry.

Indonesia spice up the world is one of the government's main programs involving crossministerial or institutional as one of the efforts to expand the marketing of Indonesian spices or processed food and spices products, as well as strengthening the industry or business in the Indonesian culinary field by developing Indonesian restaurants abroad or as part of the Indonesian culinary industry of restaurant gastro diplomacy (Kemenparekraf, 2021).

MSMEs (Micro, Small Medium Enterprise) contribute to Indonesia's GDP of 61.07 percent or equivalent to Rp. 8.573.89 trillion. The contribution of MSMEs to the Indonesian economy includes the ability to absorb 97 percent of the total workforce and collect up to 60.4 percent of the total investment (BEKRAF, 2020). MSMEs have many sectors, including the culinary business sector. The culinary business is one of the many service businesses proliferating, even in times of crisis. Food is one of the basic human needs and must always be met. Therefore, if foods and drinks are still a basic need that must be prioritized, the culinary business will continue to grow (Lujeng, 2017).

Every business activity aims to get the maximum profit to maintain the existence of a business amid competition. Therefore, the business must satisfy the needs and desires of customers to be profitable and develop rapidly. Creative and innovative ideas cause the rapid development of a business. Along with creative and innovative ideas, the marketing concept also develops. Marketing activities focus on customer satisfaction to be more precise on the target customers because potential customers will consider various factors such as product quality to make customers feel delighted and prefer our products over competing products (Hayati \& Sekartaji, 2015).

The product can be offered to the market to be noticed, used, owned, or consumed to satisfy a want or need (Firmansyah, 2019). Product quality is anything offered to the market to satisfy a want or need, including physical goods, services, experiences, events, people, places, properties, organizations, information, and ideas (Kotler, 2005). Although the number of similar competitors is a challenge for companies, companies must continue to prioritize the quality of the products sold to keep their customers satisfied.

Quality management is all management activities and functions that determine the quality policy, objectives, and responsibilities and implement them through quality management tools. Management activities and functions play a role in maintaining the level of excellence that is intended or expected, such as establishing quality policymaking, planning quality, quality assurance and control, and quality improvement. Quality management is also needed to provide quality awareness of processes within a company which requires the role of all members to achieve longterm goals in the company (Gaspersz, 2001). For example, the food and beverage industry manages the product supply cycle to all consumers in various places with special treatment for each product category and marketing channel, and it uses different distribution systems for small and large outlets (Adhi \& Santoso, 2021).

By maintaining product quality, developing innovation, and marketing promos at restaurants well, customers will continue to feel satisfied, leading to loyalty in their minds. Therefore, it is necessary to have a customer satisfaction survey to find out what the needs and desires of customers are for the company's products so that these customers will become loyal to the company. This study determines the effect of product, service quality, and customer satisfaction on customer loyalty and strategies to improve the marketing of Restaurant XYZ. 
Based on previous studies on the same theme, most of these studies rarely use only quantitative methods. Therefore, the method approach used is a mixed-method (quantitative and qualitative), and in the process, after we have analyzed and reviewed analytical tests, it is more appropriate to use logistic regression in this study.

This research aims first to know the effect of product quality, service quality, and customer satisfaction on customer loyalty in Restaurant XYZ. The second is seeing the uniqueness of Restaurant XYZ. The third is the strategies to increase the marketing of the Restaurant XYZ.

\section{Literature Review}

\subsection{Quality Product}

Product quality is the ability of a product to carry out its functions and performance, which can meet the needs and desires of customers (Kotler \& Keller, 2009). Product quality has two dimensions: the level of consistency to develop a product; the company must see and choose a quality level that will support product positioning. This quality level means the product's quality in carrying out its function so that the resulting product can be of high quality and must be maintained by the company. According to Weenas (2013), product quality can affect customer satisfaction based on product consistency free from damage. The quality of these products is usually controlled by quality management. Quality management is all management activities and functions that determine quality policies, objectives, and responsibilities and implement them through quality management tools (Gaspersz, 2001). Management activities and functions play a role in maintaining the expected level of excellence to determine quality policy, planning and development, quality assurance and control, and quality improvement.

There are eight dimensions of product quality, including performance, features, reliability, conformance, durability, serviceability, perceived quality, and aesthetics. There are also seven reasons why quality is needed for companies as a Company Reputation. For example, companies that can produce quality products or services will be judged by companies that prioritize quality and get more value in customers' eyes. First, cost reduction is needed to produce quality products or services but still oriented to customer satisfaction. Second, market improvement through cost minimization is achieved because the company can lower prices while prioritizing quality. Third, accountable products and services require companies always to be responsible for meeting customer needs and expectations in increasing market competition by producing quality products or services. Fourth, if a quality product or service can be offered and introduced to the international market, the company will give a good impression of that quality. Fifth, the appearance of products and services will be known, where the company that produces these products will be known and trusted by customers. The things above will increase customer trust and perceived quality (Gantino \& Erwin, 2010). In addition, quality is the quality of the product or service itself and the quality as a whole (total ratio) (Russell \& Taylor in Ariani, 2008).

Based on previous research, product quality is significant to customer loyalty. The higher quality the products offered at Sakinah Restaurant to customers, and the more loyal customers will be to products offered, and another previous research states that it was found that product quality has a significant effect on customer loyalty at RM Ampalu Raya Padang (Anggraeni, Kumadji, \& Sunarti, 2016; Kurnia \& Besra, 2020).

\subsection{Service Quality}

Service quality is defined to satisfy customer needs and desires and the accuracy in its delivery in balancing customer expectations. According to Tjiptono (2015), service quality is an effort made by the company to meet customer expectations for the services it receives so that the company can survive in the market and gain customer trust. Parasuraman, Zeithaml support this, and Berry (1990) that there is a gap 
between customer expectations and management perceptions, the gap between customer management perceptions and service quality specifications, the gap between service specification quality and service delivery, the gap between service delivery and external communication, the gap between expected service and expected service.

Based on previous research, service quality has a positive and significant effect on customer loyalty of internet cafe service users in Singaraja (Dewi, 2013). This shows that good service quality will increase customers' using the product or service. According to Subagyo (2010), five indicators can be determined to determine the scope of service quality. First, tangibles are material things that describe the physical form and services received by customers, and companies need to give a positive impression on the quality of services provided. Second, reliability is the ability to provide the promised service reliably and accurately. Third, responsiveness is an awareness or desire to help customers and provide services quickly, and this dimension underscores the accuracy in responding to customer requests. Fourth, safety is courtesy, knowledge, and the ability to create trust, including employee knowledge and employee behavior towards customers. Fifth, empathy is a personal concern and concern for customers, which is shown to customers through special services.

\subsection{Customer Satisfaction}

Customers are all individuals or buyers who use goods or services used continuously for personal purposes from the products offered by the company (Setyobudi \& Daryanto, 2014; Kotler \& Keller, 2009). It is also related to customer satisfaction, an expression of feelings that arise after comparing what has been achieved or to what extent the product is produced following the expectation of obtaining satisfaction or dissatisfaction, which is described as feeling happy or disappointed (Kotler \& Keller, 2009). If the product does not meet expectations (satisfaction or dissatisfaction) is described as feeling happy or disappointed, the customer will be disappointed and leave the company that remains loyal to the product/service. However, according to Sangajdi and Sopiah (2013), customer satisfaction can be maintained permanently if the company can meet customer expectations. Customer satisfaction has several aspects of intention to repurchase, and for example, customer loyalty occurs when satisfied customers are interested in buying products from companies whose performance is as expected. Because they are satisfied with the performance of companies that can meet customer expectations, these customers are challenging to persuade by competitors (Tjiptono \& Diana, 2015).

According to Lupiyoadi (2001), five factors can affect customer satisfaction: product quality, price, service quality, emotionality, cost, and ease of getting the product. Price conformity with the expected product or service quality, while service quality is based on systems, technology, and people. In addition, based on lifestyles such as cars, clothes, and others, emotional factors can cause a sense of pride when wearing these products. Finally, cost and ease of obtaining products, costs, and products are relatively easy to obtain. This is supported by Fitriani (2019) that customer satisfaction affects customer loyalty at Toko $X$ in Yogyakarta, so this means convenience and efficiency can lead to more customer satisfaction.

\subsection{Quality Management}

According to Weenas (2013), product quality can affect customer satisfaction based on product consistency and is free from damage. Therefore, quality management controls the quality of these products, which includes all activities and general management functions by determining quality guidelines, objectives, and responsibilities (Gaspersz, 2001). According to Ariani (2008), there are seven stages of quality function development: inspection, quality control, quality assurance, quality management, total quality management, learning organizations, and worldclass organizations. 


\subsection{Customer Loyalty}

Customer loyalty is deeply ingrained in purchasing or supporting the preferred product or service in the future. However, situational influence and marketing efforts can influence customers to change (Kotler \& Ketler, 2009). Loyal customers will be willing to buy even at different prices, make repeat purchases, and provide advice on the company's products or services to others (Kartajaya, 2003).

According to Dick \& Basu in Kotler (2011), there are four types of customer loyalty; namely, first, there is no loyalty because customers usually rarely shop at the same place for the second time/move places. Second, false loyalty usually customers buy because they feel suitable and want to buy elsewhere. Third, latent loyalty is a situational factor that causes customers to buy or not to make a purchase. Fourth, loyal customers will feel proud of the products used and recommend them to others. This can also be related to the characteristics of loyal customers; namely, buyers usually stick to one product and do not buy it elsewhere and recommend it to others (Griffin, 2005). Based on previous research, the quality product has a significant impact on loyalty among Porkee customers in Surabaya, along with customer satisfaction, which significantly impacts customer loyalty (Irawan \& Japarianto, 2013), and other previous research claims that service quality has a significant impact on customer loyalty to KA Lokal Bandung Raya (Agiesta, Sajidin, \& Perwito, 2021).

\section{Conceptual Framework}

Based on the studies reviewed above, product quality, service quality, and customer satisfaction affect customer loyalty. The conceptual framework is presented in Figure 3.

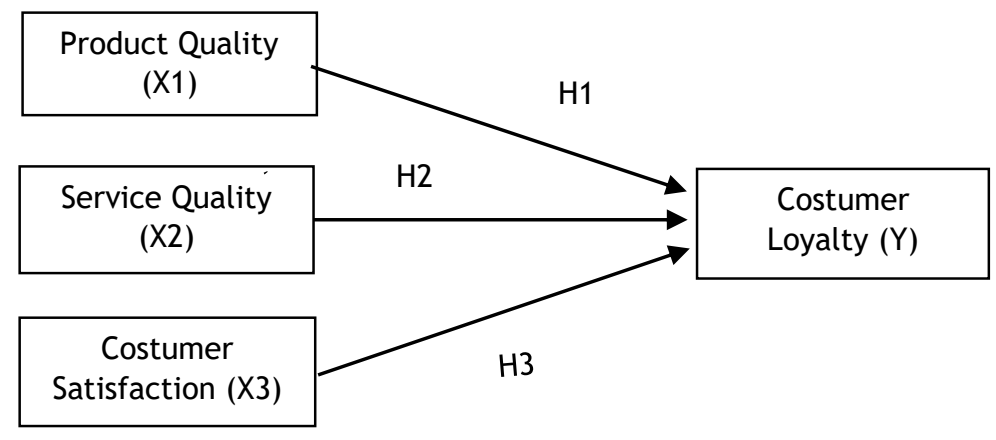

Figure 3. Conceptual framework

Based on the picture above, it can be concluded that:

H1: Quality product has a significant effect on customer loyalty

H2: Service product has a significant effect on customer loyalty

H3: Customer satisfaction has a significant effect on customer loyalty

This research used either the partial test or the Wald test to apply the framework. The null hypothesis states that the independent variable $(x)$ does not influence the response variable under consideration (in the population).

\section{Methods}

\subsection{Participants}

The variables examined in this study are product quality, service quality, customer satisfaction, customer satisfaction, and customer loyalty. The sampling technique used is incidental sampling. The data was taken by chance, anyone who met with researchers in the field who met the purchase requirements at least two times at Restaurant XYZ. The sample collected is 100 respondents of the online survey on 27 of October 2021. 
The research method used is quantitative and qualitative methods. Quantitative research is defined as testing specific theories by examining the relationship between variables. This variable is measured to analyze data consisting of numbers based on statistical procedures (Creswell, 2012). The quantitative approach is carried out in inferential research and generates conclusions from the results with zero probability of rejecting the hypothesis or indicating that the variables studied are significant or insignificant (Azwar, 2011). Qualitative research is a method that examines human experience in detail using a specific set of research techniques such as in-depth interviews, focus group discussions, observation, content evaluation, visual methods, and existence history or biographies (Hennink, Hutter, \& Bailey, 2020). This study also uses in-depth interviews with the owners of XYZ Restaurant.

\subsection{Measurement}

This questionnaire of product quality consists of eight question statements adopted by four dimensions (performance, features, durability, and serviceability) using a four-point Likert scale, namely from strongly disagree to agree strongly. Product quality is the ability of a product to carry out its functions and performance, which can meet the needs and desires of customers (Tjiptono, 2008).

This service quality questionnaire consists of eight statements adopted by five dimensions (tangibles, reliability, responsiveness, assurance, and empathy) using a four-point Likert scale: strongly disagree to agree strongly. Service quality is an effort to fulfill consumer needs and desires and accuracy in delivery in balancing consumer expectations (Subagyo,2012).

The customer satisfaction questionnaire consists of seven question statements adopted by five dimensions (product quality, price, service quality, emotional, and cost and ease of getting products) using a four-point Likert scale, namely from strongly disagree to strongly agree (Lupiyoadi, 2001).

This customer loyalty questionnaire consists of eight question statements adopted by four dimensions (repetition, purchase across the product line, retention, and recommendation) using a four-point Likert scale, namely from strongly disagree to strongly agree. Customer loyalty is a deeply held commitment to purchase or repurchase a preferred product or service in the future despite situational influences and marketing efforts having the potential to cause a customer to switch (Kartajaya, 2003).

This study's sources of data result from a questionnaire and in-depth interviews. The researcher used accidental sampling because this gives the researcher freedom to determine the sample deemed to be the most qualified. Specific sample criteria do not bind the analyst-the qualitative method by interviewing the owner of Restaurant XYZ. Quantitative data was taken by anyone who met the purchase requirements at least two times at Restaurant XYZ. The sample collected is 100 respondents, analyzed by regression logistics. The qualitative method is by in-depth interviews with the key Informant, the owner of Restaurant XYZ.

\subsection{Analysis}

The data were analyzed using a binary logistic regression model using the SPSS software. The program analyzed the effect of product quality, service quality, customer satisfaction on customer loyalty using the chi-square test. It is also used to analyze respondents' characteristics, lifestyle, and the effectiveness of product quality, service quality, and customer satisfaction on customer Loyalty. 


\section{J O U R N A L O F CONSUMER SCIENCES}

\section{Findings}

\subsection{Respondent Characteristics}

As many as 50 respondents (51\%) were male, and 49 respondents $(49 \%)$ are female (Figure 4). For the age category of the customer at Restaurant XYZ Surabaya, there are 15 - 24 years $(9 \%), 25$ - 34 years (31\%), 35 - 44 years $(47 \%)$, and 45 - 54 years $(13 \%)$ (Figure 5). Category types of work customers Restaurant $\mathrm{XYZ}$, such as private employees (55\%), entrepreneurs (19\%), housewives (10\%), students (9\%), civil $(5 \%)$, and unemployed (2\%) (Figure 6). The categories of monthly expenses for the customers of Restaurant XYZ are as follows: <Rp. 500.000 (4\%), Rp. 500,000 - Rp. 2.000.000 (15\%), Rp. 2.000.001 - Rp. 4.000 .000 (33\%), Rp. 4.000.001 - Rp. 6.000 .000 (24\%), and > Rp. 6.000 .000 (24\%) (Figure 7).

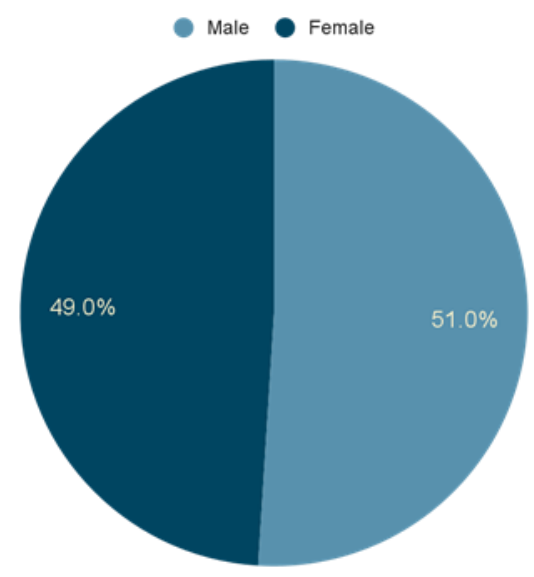

Figure 4. Respondent gender diagram

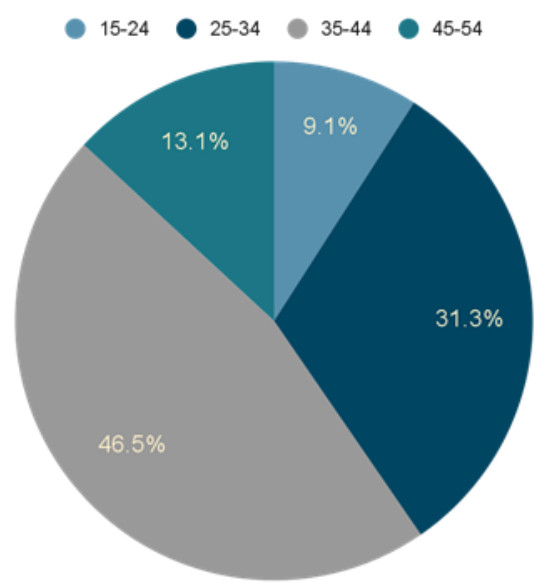

Figure 5. Respondent age's diagram 


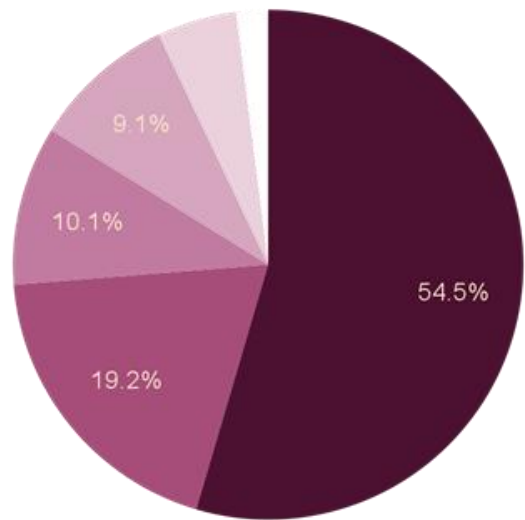

Figure 6. Respondent occupation's diagram

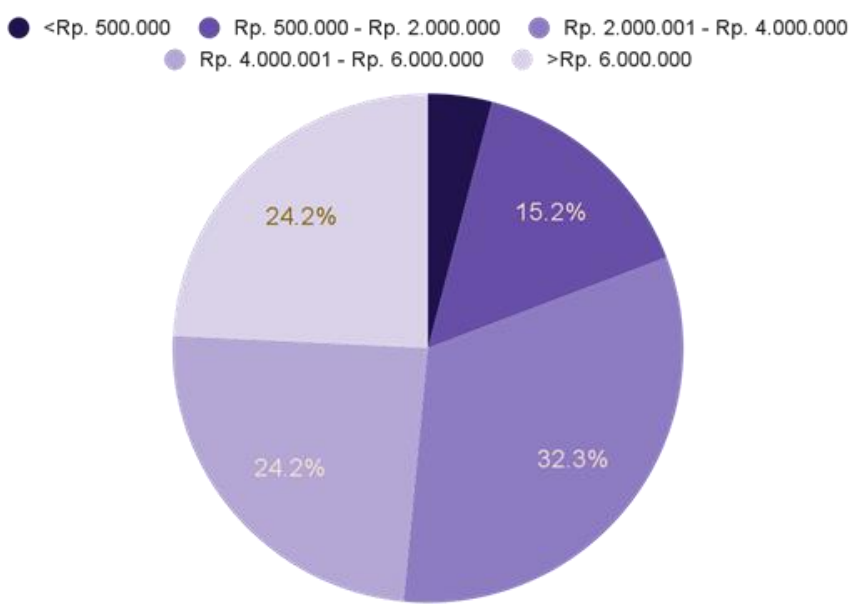

Figure 7. Respondent monthly expenses diagram

Based on the analysis and result of the questionnaire, it can be concluded that most respondents at Restaurant XYZ are male, around $35-44^{\text {th }}$ years old, their job mainly as private employees, amounted to 54 respondents $(55 \%)$, and their monthly expenses are around Rp. 2.000.001 - Rp. 4.000.000.

\subsection{Logistic Binary Model}

Table 1 show that presents the omnibus test of model coefficients. The step checks the contribution of the specific variable inserted in this step, and the block checks all variables' contributions. In contrast, the model checks the fit of the whole model. A full model test against a single constant model was statistically significant (Chi-square $=52.633, p=0.001$ with $d f=3$ ) at a significance level of 0.05 . The meaning of the Chisquare indicates that the model has at least one predictor variable that simultaneously affects the variable response. It can be concluded that the addition of independent variables (product quality, service quality, customer satisfaction) can improve the model so that it can be declared to fit or, in other words, the model can be used.

Tabel 1. Omnibus test of model coefficients

\begin{tabular}{ccccc}
\hline \multicolumn{5}{c}{ Omnibus Tests of Model Coefficients } \\
\hline \multirow{4}{*}{ Step1 } & Chi-Square & df & Sig. \\
& Step & 52.633 & 3 & $<.001$ \\
& Block & 52.633 & 3 & $<.001$ \\
& Model & 52.633 & 3 & $<.001$ \\
\hline
\end{tabular}


The equation above cannot be directly interpreted from the coefficient values like ordinary linear regression. Instead, interpretation is carried out using the value of $\operatorname{Exp}(B)$ or the exponential value of the formed regression equation coefficient. For example, from Table 2 , the $p$-value of the product quality variable is $0.034(p<0.05)$.

Table 2. Variables in the Equation

$$
\text { Variables in the Equation }
$$

\begin{tabular}{lllllllllll}
\hline & & & & & & & \multicolumn{3}{c}{$95 \%$ C.I for EXP (B) } \\
\hline & & B & S.E. & Wald & df & Sig. & Exp(B) & Lowe & Upper \\
\hline Step 1* & X1 & .615 & .291 & 4.473 & 1 & 0.34 & 1.850 & 1.046 & 3.272 \\
& X2 & -.386 & .263 & 2.147 & 1 & .143 & .680 & .406 & 1.139 \\
& X3 & .557 & .205 & 7.408 & 1 & .006 & 1.745 & 1.169 & 2.607 \\
& Constant & -23.220 & 5.546 & 17.528 & 1 & $<.001$ & .000 & & \\
\hline
\end{tabular}

The result shows that the product quality has a significant effect on customer loyalty with an influence coefficient value of 1.850 , meaning that if the product quality of Restaurant XYZ increases by 1 unit will allow deciding to be a loyal customer for 1.850 .

1. The regression coefficient for the $\mathrm{X} 1$ variable is 0.615 and has a positive value. The more Restaurant XYZ improves product quality, the greater the customer loyalty to Restaurant XYZ.

2. The regression coefficient for the $X 2$ variable is -0.386 . Therefore, it has a negative value. Therefore, it can be interpreted that the more the restaurant $\mathrm{XYZ}$ does not improve the quality of service, the less customer loyalty to Restaurant XYZ.

3. The regression coefficient for the $X 3$ variable is 0.557 , which has a positive value. The higher the customer satisfaction, the greater the customer loyalty to Restaurant XYZ.

The customer satisfaction variable also has a significant influence, as shown by the $\mathrm{p}$ value of $0.006(p<0.05)$ with a coefficient value of 1.745 , meaning that if customer satisfaction of Restaurant XYZ increases by one unit, they will increase the potential to decide to be a loyal customer for 1.745 . Nevertheless, the service quality variable has no significant influence, as shown by the $p$-value of 0.143 ( $p>0.05$ ) with a coefficient value of 0.680 . The Hosmer and Lemeshow test is presented in Table 3.

Table 3. Hosmer and lemeshow test table

\begin{tabular}{lcrr}
\hline \multicolumn{4}{c}{ Hosmer and Lemeshow Test } \\
\hline Step & Chi-Square & dF & Sig. \\
1 & 11.357 & 6 & .078 \\
\hline
\end{tabular}

It seems that the HL Goodness of Fit Test score is 11.357 with a 0.078 probability score ( $p$-value $>0.05)$, so we conclude that the model accepted. From Table 4 (model classification accuracy), those who responded agreed to 89.8 percent. Thus, the overall classification determination of the binary logistic regression model for the customer loyalty category is 76.8 percent.

Table 4. Classification

\begin{tabular}{|c|c|c|c|c|c|}
\hline \multicolumn{6}{|c|}{ Classification Table } \\
\hline Observed & & & 0 & 1 & Percentage Correct \\
\hline Step 1 & $Y$ & 0 & 23 & 17 & 57.5 \\
\hline & & $\begin{array}{c}1 \\
\text { sent }\end{array}$ & 6 & 53 & $\begin{array}{l}89.8 \\
76.8\end{array}$ \\
\hline
\end{tabular}




\subsection{Indicators}

The picture of product quality (X1) below shows that the three highest indicators of respondents are uniqueness, menu variety, and product support (Figure 8). Based on this, customers consider this product unique because of the secret ingredients of Yellow soup/yellow soup and chili sauce. In addition, XYZ Restaurant also has many menu variations such as Surabaya fried duck (a local specialty), fried chicken, rawon soup, rib soup, and many more. XYZ restaurant also has a variety of seasonings to support products such as fresh vegetables and chili sauce, which is also served with yellow sauce because the product itself has much seasoning for one serving/serving at an affordable price.

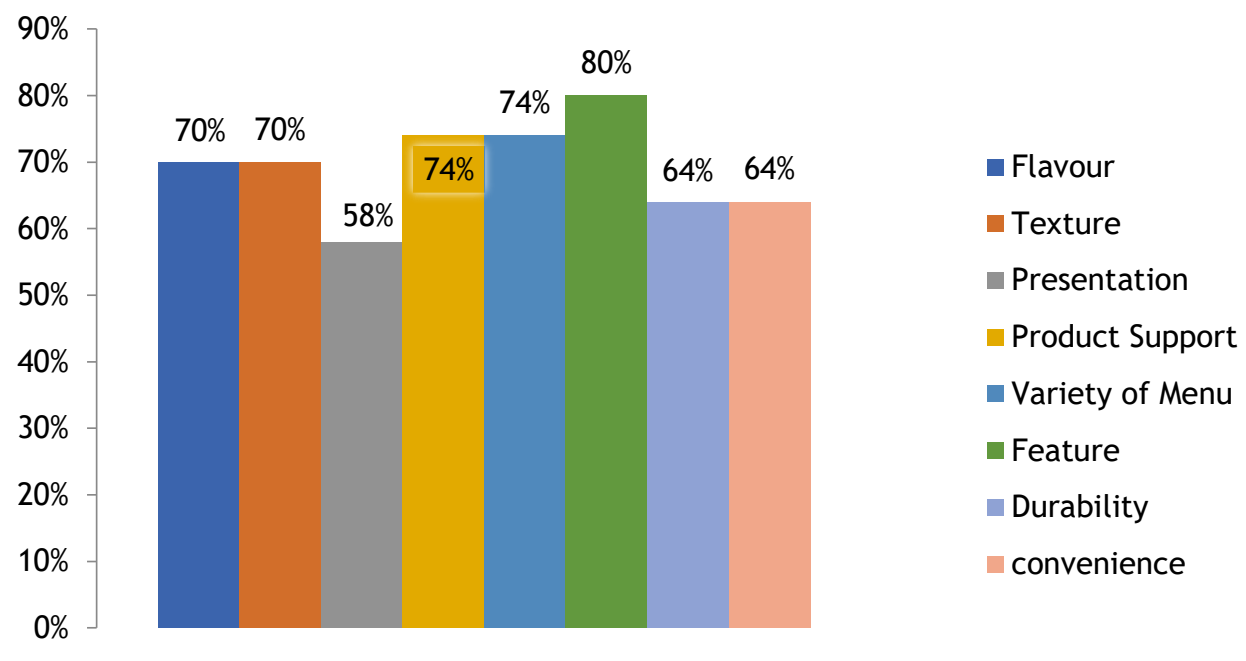

Figure 8. Product Quality

The service quality image $(X 2)$ below shows that the three highest indicators of respondents are response accuracy, attention, and product knowledge (Figure 9). Customers perceive XYZ Restaurant to respond accurately, such as customers can order online/offline (considered efficient based on current customer needs). Furthermore, XYZ Restaurant also pays sufficient attention to customers. This is because it has fast and agile employees to avoid long queues. XYZ Restaurant employees also have the extensive product knowledge to provide advice on complete menus according to customer needs.

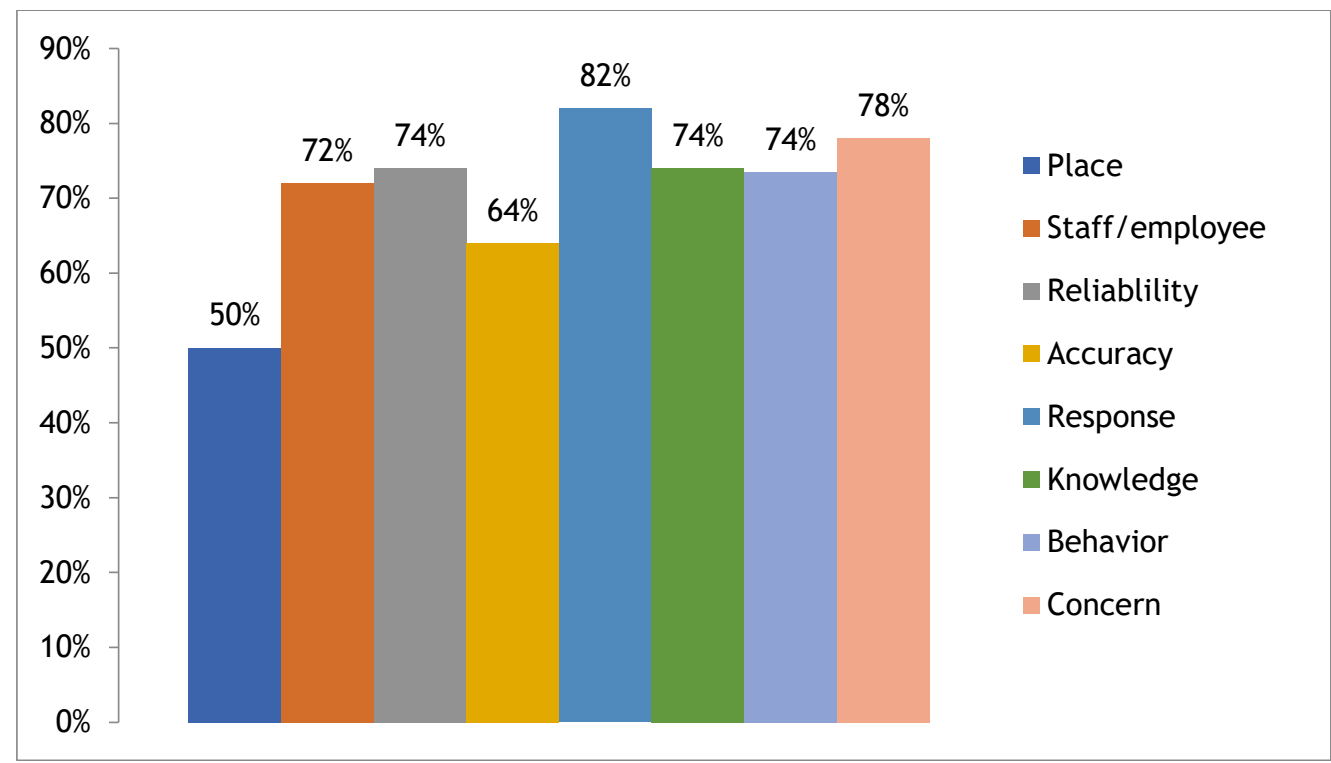

Figure 9. Service quality 


\section{J O U R N A L O F CONSUMER SCIENCES}

The Figure of customer satisfaction $(X 3)$ below shows that the three highest respondents' indicators are satisfaction, price match, and lifestyle (Figure 10). Customers who caused this felt satisfied with the quality of the products (taste, texture, complementary foods, menu variations, and features) with affordable prices for one portion served with the main product, rice, and condiments. Furthermore, the customer can enjoy the Surabaya food without spending much money because it is available in the capital city or current city where Restaurant XYZ is located.

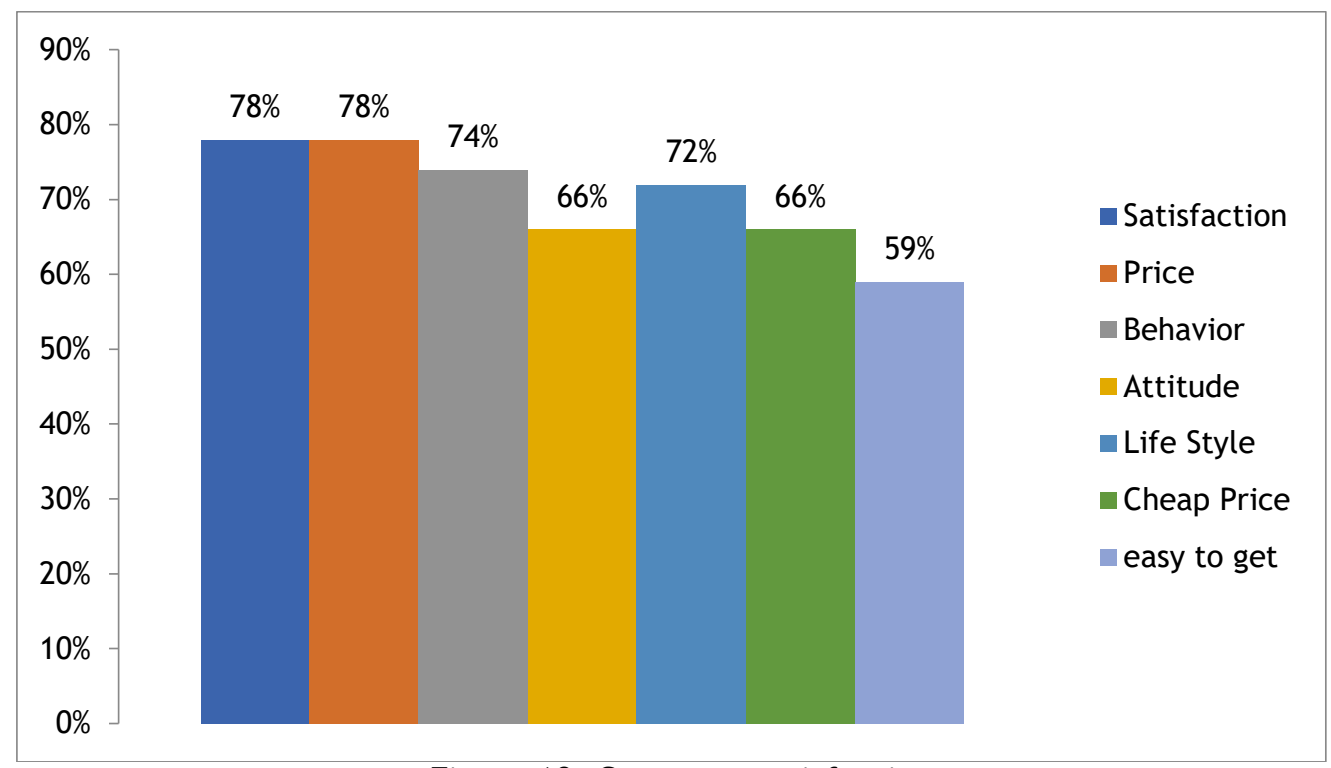

Figure 10. Customer satisfaction

The results of questionnaires and interviews show that the quality indicators of their products and services influence customer satisfaction and loyalty. The three indicators are response accuracy, product uniqueness, employee attention that makes customers happy and want to return (Figure 11). Response accuracy said that the typical Surabaya XYZ Restaurant could be ordered directly or online. The uniqueness of the product has an economical price. Customers get various choices from the available menu and are equipped with a variant of miscichi sauce and served with yellow sauce. Furthermore, employees' attention, provide friendly service, give greetings, and give individual attention to customers.

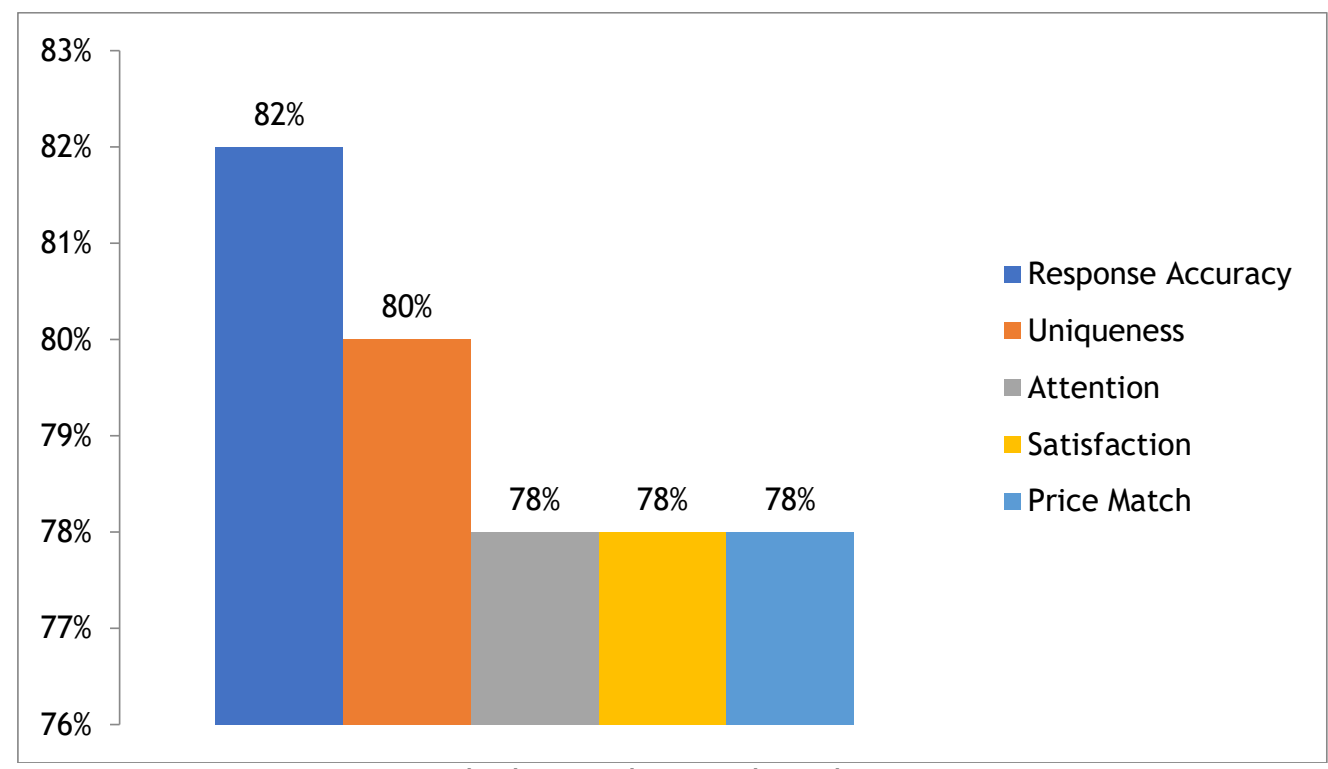

Figure 11. Five highest indicators based on a questionnaire

This restaurant was founded in 2003 and had three branches based on in-depth interviews. One of them is located at Pujasera Melawai, South Jakarta. Pujasera Melawai is one of the Jakarta Tourism Government Programs. XYZ restaurant has a 


\section{J O U R N A L O F CONSUMER SCIENCES}

variety of sauces, menus, and spices typical of the combination of Madura and Surabaya, which has a delicious and soft taste. The novelty of the miscichi duck is that it combines the unique spices of the two regions so that it has a distinctive taste. During the pandemic, the Miscichi duck made a new packaging menu that was more hygienic and small packaging in the form of "Abon Duck" at a relatively low price and could be reached by all levels of society. Duck miscichi has a Brand License at the Directorate General of Intellectual Property - Ministry of Law and Human Rights of the Republic of Indonesia and won third place in the MGK Jakarta culinary competition in 2011.

\section{Discussions}

The purpose of this study was to examine the extent to which the variables of product quality, service quality, and customer satisfaction affect customer loyalty at XYZ Restaurant. The research results were conducted using the Omnibus Test of Model Coefficients analysis technique that the model is at least one predictor variable that simultaneously affects the response variable. Supported by the equation results that product quality and customer satisfaction significantly affect customer loyalty, service quality has no significant effect on customer loyalty. According to Kotler (2011), it depends on the product concept, and consumers will favor products that offer the best quality, performance, and functionality. This is in line with previous research that the increase and decrease affect the ups and downs of customer loyalty to the quality of the products offered (Mangore, Lumanauw, \& Tielung, 2015). This is also in line with research conducted by Anggraeni et al. (2016); Reza, Sumarwan, and Hartoyo (2019), customer satisfaction significantly affects acceptable customer loyalty.

Supported by an in-depth interview by the owner who stated that XYZ Restaurant has good food ingredients and uses high-quality products to improve the quality of the products served. XYZ restaurant also has a selection of condiments. The characteristics of this restaurant that distinguish it from other duck restaurants, such as the yellow chili sauce and its various kinds of chili sauce, will continue to improve the innovation of flavors and types of cuisine to survive in the culinary competition. In addition to product quality, from the research above, it was found that customer satisfaction also has a significant influence on customer loyalty. This research is in line with research conducted by Rohana (2020) that satisfaction affects customer loyalty to store $X$ in Medan. Customer loyalty is closely related to consumer satisfaction; it means the more satisfied consumers are with their desires or satisfied between expectations and reality, which will cause consumers to return to buy the product and become loyal consumers of the product (Rachmawati, 2014).

The research results support this study by Gunawan (2013) in Bogor, which states that customer satisfaction has a significant relationship with consumer loyalty at GadoGado Boplo Restaurant. Previous research conducted by Sembiring, Sipayung, and Sitepu (2014) also states that customers will be loyal to the company when customers are satisfied, and customer satisfaction can be used as the basis for the realization of loyal or loyal customers. Previous research conducted by Susanto and Mangatua (2010) with the variable of trust, customer satisfaction, and perceived value showed that customer satisfaction and perceived values positively affected loyalty. Supported by surveys and in-depth interviews by the owner who stated that Restaurant XYZ has a high level of customer satisfaction with product quality (taste, texture, food complements, menu variations, and features) available at Restaurant XYZ and Miscichi duck's customers are satisfied with the price of the food offered, it can have a significant effect on increasing customer loyalty.

According to Kusuma and Suwitho (2018), the test results show an indirect effect between service quality and customer loyalty through customer satisfaction in using online train ticket purchasing services at Kota Baru Malang Station. The following shows that service quality is fully mediated by customer satisfaction to affect loyalty (Appley \& Lee, 2010). These results are also corroborated by research conducted by Solimun and Fernandes (2018), which states that customer satisfaction fully supports service quality to affect loyalty. They said they would invite other people to eat at 
the Restaurant $X Y Z$. They were supported by surveys and in-depth interviews by the owner, who stated that Restaurant $X Y Z$ indirectly affects service quality and customer loyalty.

This research still has limitations. First, the influence of customer loyalty in this study only consists of three variables, namely product quality, service quality, and customer satisfaction. At the same time, researchers do not test other factors that influence customer loyalty. Second, the two researchers did not test between each Variable $X$ because the researchers only focused on customer satisfaction. Third, there are limitations to research using questionnaires, where sometimes the answers given by the sample do not show the actual situation.

\section{Conclusions}

Based on the results and discussion listed and explained from the data collected, processed, and tested above, it can be concluded that Customer loyalty has the probability of 76.8 percent affected which product quality and customer satisfaction, service quality affects customer loyalty in the Restaurant XYZ. Therefore, to improve marketing, restaurant XYZ can use or implement product quality, product innovation, and marketing promotion in their menus to support the government's "spice up the world" program. Strategy to increase the marketing of Restaurant XYZ is the first is a quality product with a special blend and a special chili sauce and yellow sauce.

The second is product innovation. Restaurant $X Y Z$ is already selling frozen food and has many preparations and menus for sale. The third is marketing promotion, and the packaging is made according to an affordable price like a shredded duck, which has a size. Fourth, promoting Restaurant XYZ Surabaya with a discount on certain purchases, using posters or banners that can attract customers, hold promotions on the spot by putting up a banner that says promotions.

\section{Recommendation}

A further marketer could bring some innovation has probability 100 percent affected which product quality and customer satisfaction, service quality affects customer loyalty in the Miscichi duck's, in this case, produces outcomes that the related parties can enjoy. For example, helping to develop products and services developed by innovations is short, concise, and easy to explain to consumers. Therefore, using innovation to get has probability 100 percent affected which product quality and customer satisfaction, service quality affects customer loyalty in the Restaurant XYZ. Using paid ads or paid advertisements on social media, marketers can collaborate with other communities, associations, and investors. It is hoped that the government/university will help or synergize/collaborate in company innovation.

Further researchers could use other factors not used in this study to affect customer loyalty to Restaurant XYZ in Surabaya. Restaurant XYZ can apply various strategies to increase marketing, including product quality promoting the restaurant's social media accounts with interesting articles. The second is product innovation, creating promotional content for the restaurant using influencers, distributing testers, using innovation. Products and services developed by innovations are short, concise, and easy to explain to customers-product diversification with the advantages of Miscichi duck's. The third is marketing promotion of the restaurant's used social media accounts, creating promotional content for the restaurant using influencers, Using paid ads or paid ads on social media, Promote via social media by using referrals.

The government (central, provincial, district/city) and institutions must provide space to develop the culinary/food and beverage ecosystem sub-sector to increase the value of the supply chain to tempe-based marketing, as is the case with Spice Up the World! All possible areas. To synergize/collaborate with business people, MSME, creative economy actors, including associations and communities and universities in central/big cities to universities in districts/cities in increasing the added value and local wisdom of these spices. Thus, it has implications for managerial practices of business actors who can increase their added value in terms of product, quality, 
service, access to financing, market access, and innovation, which produces outcomes that the related parties can enjoy. In this case, for example, by helping to develop. Products and services developed by innovations are short, concise, and easy to explain to consumers and use innovation, so it is hoped that the government/university will help or synergize/collaborate in company innovation. And in the field of Using paid ads or paid advertisements on social media, we can collaborate with other communities, associations, and investors.

\section{Citation information}

Cite this article as Naini, N. F., Santoso, S., Andriani, T. S., Claudia, U. G., \& Nurfadillah. (2022). The effect of product quality, service quality, customer satisfaction on customer loyalty. Journal of Consumer Sciences, 7(1), 34-50. doi: https: / /doi.org/10.29244/jcs.7.1.3450.

\section{References}

Adhi, C., \& Santoso, S. (2021). Analysis of production performance of supply chain operation reference in PT. Premier Doughnut Indonesia. International Humanities and Applied Sciences Journal (IHASJ), 4(2), 107-115. ISSN 2622-5808.

Agiesta, W., Sajidin, A., \& Perwito. (2021). The influence of service quality and customer satisfaction on customer loyalty for local trains in Bandung Raya (Pengaruh kualitas pelayanan dan kepuasan pelanggan terhadap loyalitas pelanggan KA lokal Bandung Raya). Jurnal Ilmiah MEA, 5(2), 16531664. doi:

https: / /doi.org/10.31955/mea.vol 5.iss2.pp1653-1664

Anggraeni, D. P. (2016). The effect of product quality on satisfaction and loyalty (Pengaruh kualitas produk terhadap kepuasan dan loyalitas). Jurnal Administrasi Bisnis, 37(1), 171-177. Retrieved from https: / /media.neliti.com/media/p ublications/87178-ID-pengaruhkualitas-produk-terhadapkepuas.pdf

Appley, A. L., \& Lee, O. L. (2010). Introduction to Management (Pengantar Manajemen). Jakarta: Salemba.

Ariani. (2008). Quality Management Qualitative Side Approach (Manajemen Kualitas Pendekatan Sisi Kualitatif). Jakarta: Penerbit Ghalia Indonesia.
Azwar, S. (2011). Research Method (Metode Penelitian). Yogyakarta: Pustaka Pelajar.

BEKRAF. (2019). BEKRAF Performance Report 2019 (Laporan Kinerja BEKRAF Tahun 2019). Jakarta: Badan Ekonomi Kreatif Indonesia

Creswell, J. W. (2012). Qualitative, Quantitative, and Mixed Approach (Research Design Pendekatan Kualitatif,Kuantitatif, dan Mixed). Yogyakarta: Pustaka Pelajar.

Daryanto, \& Setyobudi, I. (2014). Customer and Excellent Service (Konsumen dan Pelayanan Prima). Yogyakarta: Gava Media. Hariasari, Ardina.

Dewi, L. R. (2013). The influence of service quality on customer loyalty of internet cafe service users in Singaraja City in 2021 (Pengaruh kualitas pelayanan terhadap loyalitas pelanggan pengguna jasa warung internet di Kota Singaraja Tahun 2021). Jurnal Pendidikan Ekonomi Undiksha, 1(1), 1-13. doi: http://dx.doi.org/10.23887/jjpe.v $1 \mathrm{i} 1.469$

Firmansyah, M. A. (2019). Product and Brand Marketing (Pemasaran Produk dan Merek). Surabaya: Qiara Media.

Fitriani. (2019). Pengaruh kualitas produk dan citra merek terhadap kepuasan konsumen dalam membentuk loyalitas (studi pada konsumen baju H\&M di Yogyakarta) (Skripsi). Sanata Dharma University, Yogyakarta, Indonesia.

Gantino, R., \& Erwin, E. (2010). The effect of quality costs on sales at PT. Guardian Pharmatama (Pengaruh biaya kualitas terhadap penjualan pada PT. Guardian Pharmatama). Journal of Applied Finance and Accounting, 2(2), 138168. doi: https://doi.org/10.21512/jafa.v2i 2.159

Gaspersz, V. (2001). Analysis for Quality Improvement (Analisa untuk Peningkatan Kualitas). 


\section{J O U R N A L O F CONSUMER SCIENCES}

Jakarta: PT. Gramedia Pustaka Utama

Goranda, I. R., Nurhayati, P., Simanjutak, M. (2021). Analysis of consumer satisfaction and loyalty factors with crm approach in agribusiness e-commerce company. Journal of Consumer Sciences, 6(2), 111-128. doi: https://doi.org/10.29244/jcs.6.2. 111-128

Griffin, J. (2005). Customer Loyalty: Growing and Maintaining Customer Loyalty (Customer Loyalty: Menumbuhkan \& Mempertahankan Kesetiaan Pelanggan). Jakarta: Erlangga.

Gunawan, I. M. P. (2013). Analisis Pengaruh kepuasan terhadap loyalitas konsumen restoran gadogado boplo Kelapa Gading Jakarta Utara (Skripsi). Institut Pertanian Bogor, Bogor, Indonesia

Hayati, Y. H., \& Sekartaji, G. (2015). Effect of product quality on customer satisfaction at Pak Ndut Solo's duck and fried chicken restaurant (Pengaruh kualitas produk terhadap kepuasan konsumen di restoran bebek dan ayam goreng Pak Ndut Solo). Jurnal Ilmiah Manajemen Fakultas Ekonomi, 1(1), 49-56. doi: https://doi.org/10.34203/jimfe.v1 i1. 455

Hennink, M., Hutter, I., \& Bailey, A. (2020). Qualitative Research Methods. London: SAGE Publication

Irawan, D., \& Japarianto, E. (2013). Analysis of the influence of product quality on loyalty through satisfaction as an intervening variable on customers of por kee restaurants in Surabaya (Analisa pengaruh kualitas produk terhadap loyalitas melalui kepuasan sebagai variabel intervening pada pelanggan restoran por kee Surabaya). Jurnal Manajemen Pemasaran, 1(2), 1-8. Retrieved from

https://media.neliti.com/media/p ublications/140415-ID-analisapenngaruh-kualitas-produkterhad.pdf

Kartajaya, H. (2003). Marketing in Venus (Pemasaran in Venus). Jakarta: PT. Gramedia. Pustaka Utama.

Kemenparekraf. (2021). Press release: 'Indonesia spice up the world' increases Indonesia's opportunities in the world culinary industry (Siaran pers: 'Indonesia spice up the world' tingkatkan peluang Indonesia di industri kuliner dunia). Retreived from

https: / /www.kemenparekraf.go.id/

Kotler, P. (2005). Marketing

Management in Indonesia: Analysis, Planning, Implementation and Control (Manajemen Pemasaran di Indonesia: Analisis, Perencanaan, Implementasi dan Pengendalian). Jakarta: Penerbit Salemba Empat

Kotler, P. (2011). Principles of Marketing (12th Edition) (Prinsipprinsip Pemasaran (Edisi ke-12)). Jakarta: Erlangga.

Kotler, P., \& Keller, K. L. (2009). Marketing Management (13th Edition (Manajemen Pemasaran (Edisi ke 13)). Jakarta: Erlangga.

Kurnia, I., Besra, E. (2020). The effect of product quality on consumer loyalty with customer satisfaction as mediating variables in Ampalu Raya Padang. Global Scientific Journal, 7(10), 1016-1031. ISSN 2320-9186

Kusuma, R. W., \& Suwitho. (2015). The effect of product quality, price, facilities and emotions on customer satisfaction (Pengaruh kualitas produk, harga, fasilitas dan emosional terhadap kepuasan pelanggan). Jurnal Ilmu dan Riset Manajemen, 4(12), 1-17

Lujeng, B. M. (2017). Analisis kualitas produk dalam meningkatkan volume penjualan pada UD Jenang Karomah Kudus (Skripsi). STAIN, Kudus, Indonesia

Lupiyoadi, R. (2001). Service Marketing Management (Manajemen Pemasaran Jasa). Jakarta: Salemba Empat

Mangore, I. I., Lumanauw, B., \& Tielung, M. (2015). Analysis of product quality, service quality and brand image to customer loyalty at tupperware Manado. Jurnal EMBA: Jurnal Riset Ekonomi, Manajemen, Bisinis, dan Akuntasi, 3(2), 616-627. doi: https://doi.org/10.35794/emba.3. 2.2015.8593

Parasuraman, A. P., Zeithaml, V. A., \& Berry, L. L. (1985). A conceptual model of service quality and its implications for future research. Journal of Marketing, 49(4), 4150. doi: 


\section{J O U R N A L O F CONSUMER SCIENCES}

https://doi.org/10.1177/00222429 8504900403

Rachmawati, R. (2014). Effect of satisfaction on customer loyalty (a study of the food business

(Pengaruh kepuasan terhadap loyalitas pelanggan (sebuah kajian terhadap bisnis makanan)).

Teknobuga, 1(1), 66 - 79. doi: https://doi.org/10.15294/teknobu ga.v1i1.6404

Reza, F., Sumarwan, U., \& Hartoyo. (2019). Satisfaction, purchasing behavior, and customer loyalty of butik emas logam mulia. Journal of Consumer Sciences, 4(2), 90107. doi: https://doi.org/10.29244/jcs.4.2. 90-107

Rohana, T. (2020). The effect of satisfaction on customer loyalty (Pengaruh kepuasan terhadap loyalitas pelanggan). Jurnal Ilmu Manajemen, 8(1), 28-32. ISSN 26152932.

Sangadji, E. M., \& Sopiah. (2013). Consumer Behavior: A Practical Approach to the Association of Research Journals (Perilaku Konsumen: Pendekatan Praktis Himpunan Jurnal Penelitian). Yogyakarta: Penerbit Andi.

Santoso, S. (2010). Application of the Multidimensional Scaling (MDS) method in planning the marketing strategy formulation of Hero Malang supermarket (Penerapan Metode Multidimensional Scaling (MDS) dalam perencanaan formulasi strategi pemasaran supermarket Hero Malang). Jurnal Teknik Industri, 1(1), 60-70. doi: https://doi.org/10.22219/JTIUMM. Vol1.No1.60-701

Santoso, S. (2020). Optimizing access to financial capital of creative economy for startups towards global competitiveness. BECOSS (Business Economic, Communication, and Social Sciences), 2(2), 13-21. doi: https://doi.org/10.21512/becossjo urnal.v2i2.6246.

Sembiring, M., Sipayung, R., \& Sitepu, F. E. (2014). Growth and production of peanuts with composting of empty palm oil bunches at different seasoning frequencies (Pertumbuhan dan produksi kacang tanah dengan pemberian kompos tandan kosong kelapa sawit pada frekuensi pembumbunan yang berbeda). Jurnal Online Agroekoteknologi, 2(2), 598-607. doi:

https://dx.doi.org/10.32734/jaet. v2i2.7066

Solimun, S., \& Fernandes, A. A. R. (2018). The mediation effect of customer satisfaction in the relationship between service quality, service orientation, and marketing mix strategy to customer loyalty. Journal of Management Development, 37(1), 76-87. doi:

https://doi.org/10.1108/JMD-122016-0315

Subagyo, A. (2010). Marketing in Business (Pemasaran dalam Bisnis). Jakarta: Mitra Wacana Media.

Susanto, B., \& Mangatua, F. W. (2010). Effect of trust, customer satisfaction, perceived value, and commitment to customer loyalty Three (Pengaruh trust, customer satisfaction, perceived value, dan commitment terhadap loyalitas pelanggan Three). Jurnal Manajemen, 5(1),17-32. Retrieved from

https: //www.semanticscholar.org/ paper/Pengaruh-Trust\%2CCustomer-Satisfaction\%2CPerceived-SusantoMangatua/9d0b2bd84deb15c42c3e 13b7f4cc823e37b0df51

Tjiptono, F. (2008). Marketing Strategy (Issue III) (Strategi Pemasaran (Edisi III)). Yogyakarta: CV. Andi Offset.

Tjiptono, F., \& Diana, A. (2015). Satisfied Customer? Not enough (Pelanggan Puas? Tak Cukup). Yogyakarta: ANDI Yogyakarta.

Weenas, R. S. (2013). (Product quality, price, promotion and service quality influence the purchase decision of spring bed comforta (Kualitas produk, harga, promosi dan kualitas pelayanan pengaruhnya terhadap keputusan pembelian spring bed comforta). Jurnal EMBA: Jurnal Riset Ekonomi, Manajemen, Bisinis, dan Akuntasi, 1(4), 607-618. Doi: https://doi.org/10.35794/emba.1. 4.2013.2741 